\title{
Implementasi Model ESQ Pada Pendidikan Agama Islam di SDN 2 Kepanjen Malang
}

\author{
Peni Catur Ningtiyas \\ Universitas Islam Negeri (UIN) Malang \\ penicaturrenaningtyas21@gmail.com
}

\begin{abstract}
The nature of postmodernism thinking teaches to review educational concepts that have been considered standard. One of them is whether enough people are only emphasized to have intellectual intelligence alone? Departing from the questions above, this research was conducted using a library study approach. Literature study is a data collection technique by conducting a study of books, literature, notes, and reports that have to do with problems that are solved. From the results of this study, there are many different kinds of intelligence that are considered more important for life. Humans can be considered more chairy if they have some kind of intelligence, which consists of IQ (Intelligence Quotient), EQ (Emotional Quotient), SQ (Spiritual Quotient) and intelligence that Emotional spiritual quostient (ESQ) plays a crucial role in educational institutions that have Islamic base is able to develop Islamic education in Indonesia. The concept can be developed as follows: the concept of freedom of heart, the pillars of faith, the pillars of Islam, and monotheism.
\end{abstract}

Key Word: Implementation, ESQ, Islamic Education

\begin{abstract}
Abstrak
Alam berfikir postmodernisme mengajarkan untuk meninjau ulang konsep-konsep pendidikan yang selama ini dianggap baku. Salah satunya adalah apakah cukup manusia hanya ditekankan untuk memiliki kecerdasan intelektual semata? Berangkat dari pertanyaan di atas, penelitian ini dilakukan dengan meng-gunakan pendekatan studi kepustakaan atau Library Research. Studi kepustakaan adalah teknik pengum-pulan data dengan mengadakan studi penelaahan terhadap bukubuku, literatur-literatur, catatan-catatan, dan laporan-laporan yang ada hubungannya dengan ma-salah yang dipecahkan. Dari hasil kajian ini, banyak ditemukan ragam kecerdasan yang justru lebih dianggap penting bagi kehidupan. Manusia bisa dianggap lebih kursial jika memiliki beberapa macam kecerdasan, yang diantaranya terdiri IQ (Intelegence Quotient), EQ (Emosional Quotient), SQ (Spiritual Quotient) dan kecerdasan yang Emotional spiritual quostient (ESQ) berperan krusial pada lembagalembaga pendidikan yang ber-basis Islam mampu mengembangkan pen-didikan Islam di Indonsia. Konsep yang bisa dikembangkan sebagai berikut: konsep kebebasan hati, rukun iman, rukun Islam, dan ketauhidan.
\end{abstract}

Kata Kunci: Implementasi, ESQ, Pendidikan Agama Islam

\section{Pendahuluan}

Manusia sangat membutuhkan pendidikan dan pengajaran dalam kehidupannya. Pendidikan merupakan usa- ha sadar, agar manusia dapat mengembangkan po-tensi dirinya melalui proses pembelajaran dan dengan cara lain yang dikenal dan diakui oleh masyarakat. 
Kenyataan pun kehidupan manusia yang berubah cepat menyebabkan tuntutan adanya pengembangan pendidikan, termasuk pendidikan Is-lam. Atas dasar itu, rancangan konseptual dan kontekstual penyempurnaan pendidikan Islam menjadi suatu keniscayaan yang harus disiapkan dan dilaksanakan.

Masyarakat adalah kelompok warga negara Indonesia non pemerintah yang mempunyai perhatian dan peranan dalam bi-dang pendidikan. UndangUndang Dasar Republik Indo-nesia Tahun 1945 Pasal 31 ayat (1) meyebutkan bahwa setiap warga negara berhak mendapat pendidikan, dan ayat (3) menegaskan bahwa Pemerintah mengusahakan dan menyelenggarakan satu sistem pendidikan nasional yang meningkatkan keimanan dan ketaqwaan serta akhlak mulia dalam rangka mencerdaskan kehidupan bangsa yang diatur dengan undang-undang. Untuk itu, seluruh komponen bangsa wajib menerdaskan kehidupan bangsa yang merupakan salah satu tujuan negara Indonesia.

Emotional spiritual quostient (ESQ) berperan krusial pada lembagalembaga pendidikan yang berbasis Islam, oleh sebab itu lembaga pendidikan haruslah bersifat fungsional, sebab lembaga pendidikan sebagai salah satu wadah dalam masyarakat biasa dipakai sebagai pintu gerbang dalam menghadapi tuntutan masyarakat, ilmu pengetahuan dan tekhnologi yang terus mengalami perubahan. Untuk itu lembaga pendidikan perlu mengadakan perubahan seiring dengan berkembangnya tuntutan dalam masyarakat yang dilayaninya. Namun kelembagaan yang akan menjadi basis sentral penanaman Sumber Daya Manusia (SDM) setidakanya sudah dapat mengakomodir harapan masyarakat luas. Pada lembaga pendidikan, perubahan seperti yang dimaksud, diadakan dalam bentuk pembaharuan pendidikan, yang diorientasikan pada pembentukan mutu yang siap pakai. Pembaharuan pendidikan itu dilakukan sebagai upaya untuk meningkatkan mutu pendidikan sehingga mampu menjawab tuntutan perkembangan zaman. ${ }^{1}$

Alam berfikir postmodernisme mengajarkan untuk meninjau ulang konsep-konsep pendidikan yang selama ini dianggap baku. Salah satunya adalah apakah cukup manusia hanya ditekankan untuk memiliki kecerdasan intelektual semata? Dari hasil kajian ini, banyak ditemukan ragam kecerdasan yang justru lebih dianggap penting bagi kehidupan. Manusia bisa dianggap lebih kursial jika memiliki beberapa macam kecerdasan, yang diantaranya terdiri IQ (Intelegence Quo-tient), EQ (Emosional Quotient), SQ (Spiritual Quotient) dan kecerdasan yang lainnya. Hal ini menjadikan manusia mem-punyai peluang mengembangkan diri, pengetahuan dan ragam pendidikan. ${ }^{2}$

2 Abd Halim Soebahar, Matrik Pendidikan Islam, (Jakarta: Kalam Mulia, 2005), h. 71

el Bidayah: Journal of Islamic Elementary Education Volume 2, Nomor 2, September 2020 
Berdasarkan permasalahan yang telah dijelaskan mengenai pentingnya pembentukan karakter sejak dini, peneliti melakukan penelitian di Sekolah Dasar Negeri (SDN) Kepanjen 2, Kabupaten Malang yang dengan kelas terpisah antara siswa laki-laki dan perempuan.

\section{Metode}

Penelitian ini menggunakan penelitian kualitatif yang dipilih peneliti karena sesuai dengan jenis penelitian deskriptif eksploratif mengungkapkan sebab akibat, penenelitian kontributif yang bermaksud mengungkap kontribusi atau sumbangan suatu kegiatan terhadap suatu prestasi dan penelitian verifikatif dengan tujuan menyakinkan peneliti atas praduga atau asumsi kebenaran sesuatu. Penelitian kualitatif merupakan metode-metode untuk mengeksplorasi dan memahami makna yang oleh sejumlah individu atau kelompok orang-dianggap berasal dari masalah sosial atau kemanusiaan. ${ }^{3}$

Teknik pengumpulan data yang di-sajikan dalam penelitian ini adalah obser-vasi, wawancara, studi dokumentasi, dan angket. Teknik analisa data yang peneliti gunakan dalam penelitian ini adalah holistik dan analisis induksi. Analisis holistik dilakukan secara menyeluruh di lapangan se-cara langsung pada saat penelitian ber-langsung. Sedangkan analisis secara induksi dilakukan setelah data terkumpul, peneliti menganalisisnya secara kritis, kemudian menafsirkannya dan pada akhirnya menarik kesimpulan sesuai dengan tujuan penelitian.

\section{Temuan dan Pembahasan}

\section{A. Paradigma Penyelenggaraan Pen- didikan Agama Islam Di SDN 2 Kepanjen}

Muhaimin, paradigma formisme me-nilai aspek kehidupan dipandang dengan "sederhana, dan kata kuncinya adalah dikotomi atau diskrit. Segala sesuatu hanya dilihat dari dua sisi yang berlawanan, seperti laki-laki dan perempuan, ada dan tidak ada, bulat dan tidak bulat, pendidikan keagamaan dan nonkeagamaan atau pendi-dikan agama dan pendidikan umum, demi-kian seterusnya".

Merujuk dari paradigma tersebut di atas peneliti memfokuskan penelitian pada pendidikan agama Islam, namun demikian tidak terlepas dari pendidkan umum deng-an tujuan mengetahui implikasi imple-mentasi pendidikan agama Islam terhadap model pembentukan karakter sebab subyek peneltian sendiri di SDN Kepanjen 2 juga mengajarkan mata pelajaran umum, dengan indikator berhasil atau tidak berhasil.

Pembentukan karakter harus dila-kukan dari sejak dini bahkan sejak anak masih dalam buaian ibunya. Karakter itu sama dengan akhlak dalam pandangan Is-lam. Abdul menjelaskan bahawa "Akhlak dalam pandangan Islam ialah kepribadian. Kepribadian itu komponennya tiga yaitu tahu (pengetahuan), sikap, dan perilaku. Yang dimaksud kepribadian utuh ialah

${ }^{3}$ Moeleong, L. .Metodologi Penelitian

Kualitatif. (Bandung:Remaja Rosdakarya, 2004), h.14 
bila pengetahuan sama dengan sikap dan sama dengan perilaku".

Karena pembentukan kepribadian sangat penting, maka paradigma pendidikannya sangat berbeda bila dibandingkan dengan pendidikan bidangbidang pengetahuan dan keterampilan. Pendekatannya adalah pendekatan untuk pendidikan kepribadian. Jelaslah akhlak atau karakter sangat penting menjadi penanda seseo-rang itu layak atau tidak layak disebut manusia. Karena itu pendidikan akhlak adalah bidang pendidikan yang terpenting.

Abdul Majid, menjelaskan bahwa" Pertama pendidikan akhlak atau karakter adalah tugas semua orang yang berdekatan dengan anak didik termasuk pembuat kebijakan. Pendidikan akhlak di sekolah adalah tugas kepala sekolah, guru agama, semua guru yang lain, dan warga sekolah. Kedua pendidikan akhlak sedikit saja berupa pengisian pengetahuan kognitif, bahkan akhlak tidak usah diajarkan secara kognitif".

Akhlak atau karakter diajarkan melalui metode internalisaai teknik pendidikannya menggunakan peneladanan, pembiasaan, penegakan peraturan, pelatihan dan pemotivasian, bukan dengan cara menerangkan atau mendiskusikan, jika pun perlu hanya cukup sedikit saja dilakukan untuk mengetahui respon peserta didik dalam mengikuti proses pembelajaran dengan bimbungan guru baik di kelas mau pun di luar kelas.

\section{B. Pendidikan Islam}

Pendidikan Islam bertujuan untuk memberikan penyadaran kepada peserta didik akan dirinya sebagai seorang hamba (khalifah) yang mengerti akan kelebihan yang diberikan kepadanya; dengan de-mikian diharapkan setelah memperoleh pendidikan peserta didik sampai pada tujuan akhir dari seluruh aktifitas umat manusia yaitu takwa. Hal ini pula yang seharusnya memberi kesadaran penuh kepada peserta didik untuk mengerti apa saja yang memberinya jalan terang.

Seiring berubahnya zaman pemikiran dan orientasi manusia pun ikut berubah ${ }^{4}$ Dibarengi dengan tujuan-tujuan singkat keduniawian yang menganggap pendidikan sebagai sebuah investasi masa depan untuk meraih kehidupan dunia yang lebih baik, kemudian mengedepankan hasil dari pada proses panjang yang seharusnya dilalui. ${ }^{5}$ Dengan demikian tujuan yang dicapai bukan buah instant yang hanya mampu bertahan sesaat tetapi pandangan dasar yang terbersit dalam angan manusia itu kemudian akan menggerakkan seluruh manifestasi serta gerak langkahnya.

Pandangan tersebut tidak luput mempengaruhi pendidikan Islam, sehingga terjadi kekeliruan yang akhirnya menyebabkan seorang hamba lupa tujuan akhiratnya. Disini letak pentingnya sebuah proses dan sebuah proses itu harus dimulai dengan niat.

${ }^{4}$ Muhammad Quthb, Sistem Pendidikan Islam terj. Salman Harun, (Bandung: Al Maarif, 1993), h. 17.

5 Zamroni, Paradigma Pendidikan Masa Depan; (Yogyakarta: Bigraf Publishing, 2001), h. 34-35 
Allah berfirman di dalam Al Qur'an Surat Al A'raf ayat 172 sebagai berikut:

Terjemahannya: Dan (ingatlah), ketika Tuhanmu mengeluarkan keturunan anak-anak Adam dari sulbi mereka dan Allah mengambil kesaksian terhadap jiwa mereka (seraya berfirman): "Bukankah Aku ini Tuhanmu?" Mereka menjawab: "Betul (Engkau Tuhan kami), kami menjadi saksi". (Kami lakukan yang demikian itu) agar di hari kiamat kamu tidak mengatakan: "Sesungguhnya kami (bani Adam) adalah orang-orang yang lengah terhadap ini (keesaan Tuhan)".

Ada dua hal yang penulis tekankan berkenaan ayat ini adalah pertama bahwa manusia tidak lahir "bim salabim" namun ada sebuah proses yang dilaluinya, kedua ayat ini juga memberikan peringatan kepada setiap jiwa manusia untuk meluruskan niat mengingat perjanjian yang telah di sepakati. Persoalan proses dengan niat ini sangat penting karena menentukan arah pencitraan diri seseorang dalam proses pendidikan, dari persoalan pemahaman yang berbeda tentang hakikat pendidikan Islam.

Islam sangat menginginkan arus hu-bungan antara tujuan akhir setiap individu yang menghambakan diri kepada-Nya dengan tujuan sementara berupa penghidupan yang layak dan duniawi terpelihara sehingga memberikan petunjuk dalam perjalanan (pekerjaan duniawi), kesadaran hakekat kehidupan memberikan perasaan lapang dan tidak mudah dihinggapi penat dan stress, dengan kesadaran itu pula akhirnya mengembalikan segala sesuatunya keharibaan Allah SWT.

Ilmuan Islam sejati selalu mengedepankan tanggung jawab dirinya sebagai seorang hamba seperti keluarga dan lingkungannya, rasionalisasi antara teori keilmuan yang dipelajarinya dengan realitas masyarakat harus seiring sejalan pada yang benar. Hal ini bertujuan untuk mencapai hakekat pendidikan Islam, karena gelar keduniawian yang kita sandang hari ini belum tentu mengantarkan kita ke dalam sorga bahkan diceritakan di dalam buku Sholeh Chambali mengenai hal tersebut:

"Dan meriwayatkan oleh setengah ulama bahwa sesungguhnya orang yang lari dari pada ahlinya itu seperti menempati hamba yang lari dari tuannya yaitu tiada diterima baginya sembahyangnya dan tiada diterima pula puasanya hingga kembali kepada ahlinya (dan) diriwayatkan oleh setengah ulama banwa sesungguhnya pertama-tama yang bergantung de-ngan seorang laki-laki pada hari kiamat itu yaitu ahlinya dan anaknya ma-ka memperbantahkan mereka itu akan dia antara hadapan Allah ta'ala maka berkata oleh segala ahlinya: hai tuhanku ambil olehmu dengan hak kami dari pada lakilaki ini bahwa sungguhnya orang ini tiada menga-jarkan akan kami akan satu hukum yang kami jahil akan dia". 6

Penyatuan dua unsur dasar manusia baik jasmani maupun rohani ke dalam sebuah kaidah pemikiran pendi-

6 Soleh Chambali, Intan Berlian Laki Perempuan, (Surabaya: Penerbit Salim Nabhan dan Ahmad, 1951), h. 15 
dikan Islam yang komprehensip selalu di dasarkan pada tauhid kepada Allah. Untuk melihat lebih jauh hakikat pendidikan Islam tercermin dalam perumpamaan pendidikan yang diberikan Luqman kepada anak-anaknya di dalam surat al Luqman 15-17.

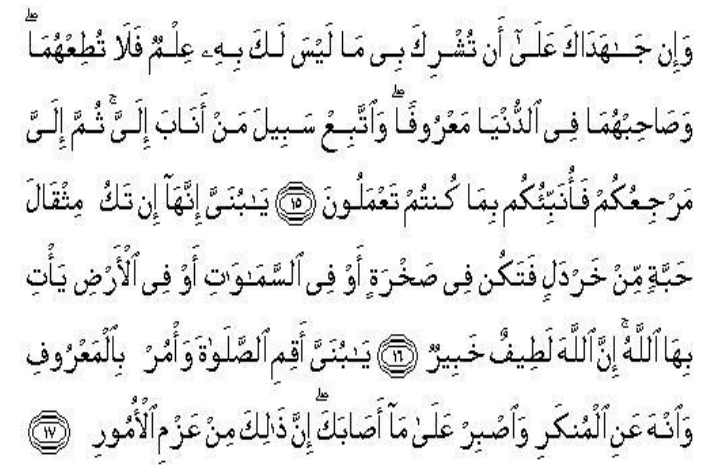

Terjemahannya: Dan jika keduanya memaksamu untuk mempersekutukan dengan Aku sesuatu yang tidak ada pengetahuanmu tentang itu, maka janganlah kamu mengikuti keduanya, dan pergaulilah keduanya di dunia dengan baik, dan ikutilah jalan orang yang kembali kepada-Ku, kemudian hanya kepadaKulah kembalimu, ma-ka Kuberitakan ke-padamu apa yang telah kamu kerjakan. (Luqman berkata): "Hai anakku, sesungguhnya jika ada (sesuatu perbuatan) seberat biji sawi, dan berada dalam batu atau di langit atau di dalam bumi, niscaya Allah akan mendatang-kannya (mem-balasi-nya). Sesungguh-nya Allah Maha Halus lagi Maha Mengetahui. Hai anakku, dirikanlah shalat dan suruhlah (manusia) mengerjakan yang baik dan cegah-lah (mereka) dari perbuatan yang mungkar dan

${ }^{7}$ A.Syafi'I Ma'arif, dkk., Pendidikan Islam di Indonesia antara Cita dan Fakta, (Yogyakarta: Tiara Wacana, 1991), h. 56-57

42 bersa-barlah terhadap apa yang menimpa kamu. Sesung-guhnya yang demikian itu termasuk hal-hal yang diwajibkan (oleh Allah). ${ }^{7}$

Kisah Luqman di atas menjelaskan beberapa rumusan penting dan dominan untuk mencapai hakekat pendidikan Islam antara lain:

a. Luqman menyampaikan prinsip tauhid dan larangan syirik kepada putra putrinya.

b. Luqman mengajarkan ilmu pengetahuan (hikmah) dan batasan potensi manusia untuk mengetahui sesuatu.

c. Luqman mengajarkan sholat untuk menumbuhkan amal shaleh.

d. Luqman mendidik putra-putrinya akhlaqul karimah, baik pada diri sendiri, sesama manusia, alam terutama kepada Allah SWT.

e. Luqman mendidik putra-putrinya untuk melakukan amar ma'ruf nahi mungkar. ${ }^{8}$

\section{Penerapan Model ESQ}

Konsep-konsep dasar dalam penerapan ESQ sebagai berikut:

\section{Kebebasan Hati}

“...... Sungguh, Allah tidak akan mengubah (nasib) satu kaum jika mereka tidak mengubah keadaan-Nya sendiri..." (QS Ar Ra'd :11)

Sebagai manusia kita harus mampu menjelaskan bahwa kita sesungguhnya me-miliki kebebasan untuk memilih reaksi terhadap segala sesuatu yang terjadi atas diri kita. Kitalah penanggung

${ }^{8}$ Moch Eksan, Kiai Kelana Biografi Kiai Muchith Muzadi, (Yogyakarta: LkiS, 2000), h. 30

el Bidayah: Journal of Islamic Elementary Education Volume 2, Nomor 2, September 2020 
jawab utama atas sikap yang kita ambil, bukan ling-kungan kita. Diri kita sendiri sesungguhnya penentu pilihan tersebut.

Manusia sebagai makhluk berpendidikan yang mempunyai kecenderungan untuk berbuat kebaikan, maka kita harus menghindari dari "belenggubelenggu" yang membuat manusia menjadi buta yaitu:

a. Berprasangka negatife

b. Prinsip hidup yang salah. Pengalaman-pengalaman yang membelenggu pikiran. Kepentingan yang sangat subjektif.

c. Sudut pandang yang tidak bijaksana

d. Fanatisme yang berlebihan. ${ }^{9}$

2. Rukun Iman: Prinsip Membangun Kecerdasan Emosi ${ }^{10}$

1. Iman kepada Allah atau Star Principle

Diperlukan sebuah kesungguhan untuk memahami suara hati, atau nilainilai dasar spiritual. Perlu disadari bahwa (99 Asmaul Husna) suara hati adalah satu kesatuan yang tidak berdiri secara terpisah-pisah. Maka pelajarilah sifat-sifat Allah secara menyeluruh, agar kita mampu membangun kecerdasan emosi dan spiritual yang terintegrasi.. Pemahaman dan pemaknaan suara hati sebaiknya tidak dengan me-ngambil sepotong atau sebagaian sesuai se-lera pribadi saja, tidak pula dengan mengabaikan sifat-sifat yang lain.

\footnotetext{
${ }^{9}$ Ary Ginanjar Agustian, Rahasia Sukses Membangun Kecerdasan Emosi dan Spiritual' ESQ, Emotional, Spiritual Quottient. The ESQ Way 165, 165, 1 Ihsan 6Rukun Iman dan 5 Rukun Islam, ( Jakarta: ARGA Publishing, 2007), h. 48

10 Ary Ginanjar Agustian, Rahasia Sukses Membangun Kecerdasan Emosi dan Spiritual' ESQ, Emotional, Spiritual Quottient. The ESQ Way
}

Pemahaman sifat-sifat Allah mesti diawali dengan proses penjernihan hati menuju keadaan yang suci dan bersih. mampu berdiri sendiri, tetapi harus juga suci, bersikap rahman dan rahim, adil dan bijaksana. ${ }^{11}$

Segala keputusan yang akan kita ambil, jika dilandasi niat karena Allah, maka di da-lamnya anda akan temukan kebi-jaksanaan mulia, rasa aman, kepercayaan diri, inte-gritas, kebijaksanaan, motivasi. Proses pengambilan keputusan ini adalah proses dimana anda dihadapkan pada ber-agam dorongan suatu hati. Seperti dorongan ingin berkuasa tidak akan mampu berdiri sendiri, tetapi harus juga suci, bersikap rahman dan rahim, adil dan bijaksana. 99 sifat-sifat Allah merupakan sumber suara hati.

2. Iman kepada Malaikat atau Angel

Principle

Malaikat adalah makhluk mulia, dan mereka sangat dipercaya oleh Tuhan untuk menjalankan segala perintah-Nya. Semua pekerjaan dilakukan dengan sebaik-baiknya, apa pun pekerjaan yang diberikan kepada mereka. Prinsipnya tunggal hanya mengabdi kepada Allah. Malaikat memiliki kesetiaan tiada tara, bekerja tanpa kenal lelah, tak memiliki kepentingan lain selain menyelesaikan pekerjaan yang diberikan oleh Allah hingga tuntas. Mereka sangat disiplin dalam menjalankan tugas dengan hasil

165, 165, 1 Ihsan 6Rukun Iman dan 5 Rukun Islam, ( Jakarta: ARGA Publishing, 2007), h. 106.

11 Ary Ginanjar Agustian, Rahasia Sukses Membangun Kecerdasan Emosi dan Spiritual' ESQ, Emotional, Spiritual Quottient. The ESQ Way 165, 165, 1 Ihsan 6Rukun Iman dan 5 Rukun Islam, ( Jakarta: ARGA Publishing, 2007), h, 119. 
sangat memuaskan. Semua system yang berada di bawah tanggungjawabnya berjalan dengan sangat sempurna.

Kepercayaan itu diberikan langsung oleh Tuhan, dan malaikat secara sungguh-sungguh mampu menjaganya. Keteladanan malaikat adalah contoh bagi manusia tentang integritas sesungguhnya adalah integritas total yang menghasilkan suatu kepercayaan tingkat tinggi. Keteladanan yang bisa diperoleh dari sifat malaikat secara umum adalah menjaga teguh kepercayaan, memiliki loyalitas, dan komitmen, kebiasaan memberi dan mengawali, kebiasaan menolong. Sikap sepeti ini yang harus ada dalam dunia pendi-dikan, sebagai bentuk pembaharuan pendidikan Islam.

3. Percaya Kepada Nabi Allah atau Leadeship Principle

Selama ini, terjadi kekeliruan pemahaman tentang arti kepemimpin. Banyak orang mengartikannya sebagai kedudukan atau posisi yang tinggi saja. Sehingga, posisi pemimpin diincar demi mendapatkan ke-dudukan tinggi dalam sebuah kelompok. Dengan paradigma itu, sebagian orang akan menghalalkan segala cara untuk menjadikan pemimpin. Mulai dengan membeli, menjilat atasan, menyikut lawan, dan cara lainnya.

Pemimpin sejati adalah seseorang yang selalu mencintai dan memperhatikan kepada orang lain, sehingga ia dicintai. Memiliki integritas yang kuat, sehingga ia dipercaya oleh pengikutnya. Selalu membimbing dan mengajari pengikutnya. Memiliki kepribadian yang kuat dan konsisten. Dan yang terpenting adalah me-mimpin berlandasan suara hati yang fitrah.

4. Iman Kepada Kitab Allah atau Learning Principle

Al Qur an adalah pembimbing menuju kebahagiaan. Memberikan prinsip dasar yang dapat dijadikan pegangan untuk mencapai keberhasilan dan kesejahteraan, baik lahir maupun batin dan memberikan peneguhan agar manusia memiliki kepercayaan diri yang sejati dan mampu memberikan motivasi yang kuat dan prinsip yang teguh. Semua dijelaskan secara terperinci dan lengkap.

Al Qur an mengintegritaskan kita terhadap memiliki kebiasaan membaca buku dan membaca situasi dengan cermat. Selalu berpikir kritis dan mendalam. Selalu mengevaluasi pemikirannya kembali. Bersikap terbuka untuk mengadakan penyempurnaan. Memiliki pedoman yang kuat dalam belajar.

\section{Iman Kepada atau Vision Principle}

Di dalam prinsip ini, langkah pembangunan visi dimulai. Setiap tahapan pembangunan sangat bergantung pada kualitas kecerdasan hati seseorang, yang sejatinya telah dipersiapkan di pembangunan prinsip-prinsip sebelumnya. Di dalam sebuah visi atau tujuan awal disitu akan menuju titik tujuan akhir yang harus dicapai. Oleh karenanya, setiap menugaskan suatu pekerjaan, sentuhlah sang hati terlebih dulu, bukan pikiran dalam kepalanya. Berikan pemaknaan pada hatinya dengan menjelaskan tujuan akhir apa yang sesungguhnya harus dicapai. Yakinlah akan adanya masa depan, sehingga memiliki

el Bidayah: Journal of Islamic Elementary Education Volume 2, Nomor 2, September 2020 
kendali diri dan sosial, memiliki kepastian akan masa depan, dan ketenangan batiniah yang tinggi.

\section{Iman Kepada Ketentuan Allah atau} Well Organized Principle

Hari akhir (kiamat) adalah takdir Allah. Tetapi, selama ini, sebagian orang memahami takdir secara sepotongsepotong, tanpa melihat proses keseluruhannya. Mereka beranggapan, keberhasilan atau kegagalan seseorang semata-mata karena takdir Tuhan. Pada setiap proses yang akan dan telah kita lalui, terdapat takdir atau hukum ketetapan Tuhan, yang bersifat pasti. Namun kita berhak untuk memilih setiap langkah yang akan menentukan takdir kita. ${ }^{12}$

\section{Lima Rukun Islam sebagai Dimensi Fisik Manusia}

Pelaksanaan pada dimensi fisik seseorang harus memiliki lima pedoman berdasarkan rukun Islam. Pertama, ia me-miliki mission statement yang jelas yaitu "dua kalimat syahadat" sebagai tujuan hidup dan komitmen kepada Tuhan. Syahadat akan membangun sebuah keyakinan dalam berusaha. Syahadat akan menciptakan suatu daya dorong dalam upaya mencapai tujuan. Syahadat akan membangkitkan keberanian serta optimisme, sekaligus menciptakan ketenangan batin dalam menjalankan misi hidup.

Kedua, memiliki sebuah metode pembangunan karakter (Character Building) melalui "shalat lima waktu". Shalat

12 Ary Ginanjar Agustian, Rahasia Sukses Membangun Kecerdasan Emosi dan Spiritual' ESQ, Emotional, Spiritual Quottient. The ESQ Way 165, 165, 1 Ihsan 6Rukun Iman dan 5 Rukun Islam, ( Jakarta: ARGA Publishing, 2007), h, 122. adalah metode relaksasi untuk menjaga kesadaran diri agar tetap memiliki cara berpikir yang jernih. Sholat adalah suatu langkah untuk membangun kekuatan afir-masi. Shalat adalah sebuah metode yang dapat meningkatkan kecerdasan emosi dan spiritual secara terus-menerus. Shalat ada-lah teknik pembentukan pengalaman yang membangun suatu paradigma positif (new paradigm shift). Dan sholat adalah suatu cara untuk terus mengasah dan memertajam ESQ yang diperoleh dari Rukun Iman.

Ketiga, memiliki kemampuan pengendalian diri (Self Control) yang dilatih dan disimbolkan dengan "puasa". Puasa adalah suatu metode pelatihan untuk pengendalian diri. Puasa bertujuan untuk meraih kemerdekaan sejati, dan pembebasan diri belenggu yang tak terkendali. Puasa yang baik akan memelihara asset kita yang paling berharga, yaitu suara hati illahiah, dan tujuan hidup sesungguhnya.

Ketiga nilai tersebut akan menghasilkan ketangguhan pribadi dalam diri peserta didik, dua nilai selanjutnya dikeluarkan melalui zakat dan Haji. Kedua nilai inilah yang nantinya akan menghasilkan ketangguhan sosial. ${ }^{13}$

\section{Tauhid Total}

Ketika seseorang telah mengganti prinsip hidupnya dari materialism menuju tauhid total maka akan terlihat keadaan batinnya. Emosi yang muncul adalah ketenangan atau dalam keadaan stabil. Hal ini terjadi karena prinsip dan

13 .Syafi'I Ma'arif, dkk., Pendidikan Islam di Indonesia antara Cita dan Fakta, (Yogyakarta: Tiara Wacana, 1991), h. 80--81 
pusat orbit yang diambil "berpegang kepada Sang Maha Esa" Selanjutnya suara hati yang muncul adalah sabar, konsisten, amanah dan ikhlas. ${ }^{14}$

Dalam dunia pendidikan islam, standar idealnya di ukur dengan konsep melangit, jelas secara tidak langsung di paksakan untuk di cangkokkan dalam pendidikan Islam, padahal dari sisi kesejarahan dan kultur yang di bangun sangat jauh berbeda dengan realitas yang ada. Setidaknya walau hal itu sudah menjadi keniscayaan, minimal ada standar atau filter yang mampu untuk menjinakkan hal tersebut, semisal pertama kali, melalui proses pengislaman, sehingga besar kemungkinan umat Islam sebagai konsumennya tidak tersentak melihat fenomena yang beda akibat sebuah persoalan yang terjadi dalam dunia pendidikan.

Dengan demikian, ESQ Model walau dalam dataran fakta, ia mengungkap secara umum tentang pendidikan, namun ia mampu memberikan kontribusi riil dalam mewujudkan pembaharuan pendidikan Islam, sehingga terdapat ciri khas yang mampu mewujudkan Pendidikan Islam di Indonesia menjadi sebuah model yang bisa dijadikan rujukan untuk menciptakan pendidikan berkarakter dan berbudi luhur yang tinggi sesuai dengan tuntunan agama Islam.

\section{Keberhasilan Penerapan Model ESQ}

\footnotetext{
14 Majid, A, \& Dian, A. (2013).
$\begin{aligned} & \text { Islam. } \\ & \text { Pendidikan Karakter }\end{aligned}$

$\begin{array}{rll}14 \text { Majid, A, \& Dian, A. } & \begin{array}{l}\text { (2013). } \\ \text { Islam. }\end{array}\end{array}$ (Bandung:Remaja Rosdakarya, 2013), h.15 46
}

Keberhasilan mengimplementasikan model internalisasi nilai-nilai pendidikan agama Islam dengan pembentukan karakter di SDN 2 Kepanjen dapat diukur dari capaian-capaian internalisasi nilai-nilai dan akhlakul karimah meliputi aspek kognitif, afektif, dan psikomotor. secara real ketiga aspek/ ranah tersebut tidak mungkin dipisah-pisahkan mana yang lebih urgen sebab ketiga saling berkaitan saling mendukung oleh sebab itu ketiga aspek kognitif, afektif, dan psikomotor sebaiknya dilatih secara simultan sehingga peserta didik memiliki kompetensi yang lengkap dengan demikian peserta didik dapat dengan mudah mengatasi hambatan dan penuh percaya diri menatap masa depan yang lebih baik. Beni Ahmad Saebani, menjelaskan "karakter adalah tindakan yang berhubungan dengan tiga unsur penting kognitif, afektif, dan psikomotor "dirinci lagi oleh peneliti sebagai berikut.

a) Kognitif, yaitu pengetahuan dasar manusia melalui potensi intelektualitasnya.

b) Afektif, yaitu pengembangan potensi akal manusia melalui upaya menganalisis kejadian sebagian bagian pengembangan ilmu pengetahuan.

c) Psikomotorik, yaitu pelaksanaan pemahaman rasional ke dalam perbuatan yang konkret.

Memahami tingkat perkembangan agama anak-anak dalam menerapkan model ineternalisasi ESQ pada PAI di

el Bidayah: Journal of Islamic Elementary Education Volume 2, Nomor 2, September 2020 
SDN 2 Kepanjen, guru lebih fokus melatih dan membiasakan perilaku yang mulia dengan teladan yang baik sehingga peserta didik menunjukkan akhlakul karimah sesuai harapan orang tua peserta didik, guru sebagai pendidik, bangsa dan negara Inonesia tercinta. Merujuk pendapat Jalaludin, bahwa "perkembangan agama anak-anak melalui tiga fase the fairy tale stage, the realistik stage, dan the individual stage" dirinci selanjutnya oleh peneliti yaitu.

- The Fairy Tale Stage (Tingakat dongeng) Tingkatan ini dimulai pada anak yang berusia 3-6 tahun. Pada tingkat ini konsep mengenai Tuhan lebih banyak dipengaruhi oleh fantasi dan emosi.

- The Realistik Stage (Tingkat kenyataan) Tingkat ini dimulai sejak anak-anak masuk sekolah dasar hingga ke usia adolesense. Konsep mengenai Tuhan diperoleh melalui lembaga-lembaga keagamaan dan pengajaran agama dari orang dewasa. Pada masa ini ide keagamaan anak didasarkan atas dorongan emosional.

- The Individual Stage (Tingkat individu) Pada tingkat ini anak telah memiliki kepekaan emosi yang paling tinggi sejalan dengan perkembangan usia mereka.

Sejatinya, perubahan setiap tingkatan dipengaruhi oleh faktor intern, yaitu perkembangan usia dan faktor ekstern pengaruh luar yang dialaminya.

Ranah keberhasilan capaian kognitif, afektif, dan psikomotor merupakan penunjang keberhasilan penanaman karekter peserta didik di SDN 2 kepanjen, Kabupaten Malang sebab u- mum orang yang memiliki akhlakul karimah memiliki pengetahuan yang baik (kognitif), memiliki sikap yang baik (afektif), pengamalan/perilaku yang baik juga (psikomotor)

Kenyataannya ketiga ranah kognitif, afektif, dan psikimotor tidak dapat dipisahkan satu dengan yang lain, sebab ketiga saling berkaitan ranah kognitif merupakan pengetahuan dasar manusia dengan menggunakan potensi intelektualitasnya sedangkan ranah afektif merupakan pengembangan ilmu pengetahuan dari kemampuan intelektualitasnya sehingga potensi akal manusia muncul dengan menganalisis berbagai kejadian sebagai bagian pengembangan kemampuan intelektualitasnya yang melahirkan sikap kemampuan menilai perbuatan baik atau buruk, dan ranah psikomotorik merupakan perpaduan ranah kognitif dan afektif melahirkan pemahaman rasional sehingga mendorong seserang melakukan perbuatan konkret yang akan berupaya berkata, berperilaku, dan berbuat dalam koridor kebaikan dan kemuliaan singkat kata memiliki akhlakul karimah.

Sebagai hasil penelitian, peneliti mampu menemukan keberhasilan capaian ranah kognitif Syarat-syarat yang telah ditetapkan dengan indikator keberhasilan beru-pa nilai dan angka yaitu KKM, syarat kenaikan kelas dapat dilampaui oleh kelas I sampai dengan kelas $\mathrm{V}$, sehingga kelas I sampai kelas $\mathrm{V}$ dinyatakan naik kelas seluruhnya $100 \%$ dalam artian tidak ada yang mengu-lang dan khusus kelas VI. Selain memenuhi syarat kelulusan harus memennuhi pula syarat kenaikan kelas hal tersebut dapat dilampaui dengan baik, ditunjukkan 
dengan semua siswa kelas VI yang berjumlah 130 siswa dinyatakan lulus $100 \%$.

\section{Kesimpulan}

Berdasarkan kajian di atas, dapat disimpulkan bahwa Emotional spiritual quostient (ESQ) berperan krusial pada lembaga-lembaga pendidikan yang berbasis Islam mampu membntuk karakter siswa sesuai konsep yang dikembangkan dari konsep kebebasan hati, rukun iman, rukun Islam, dan ketauhidan.

\section{Daftar Pustaka}

Agustian, Ary Ginanjar, 2007, Rahasia Sukses Membangun Kecerdasan Emosi dan Spiritual' ESQ, Emotional, Spiritual Quottient. The ESQ Way 165, 1 Ihsan 6Rukun Iman dan 5 Rukun Islam, (Jakarta: ARGA Publishing).

Agustian, Ary Ginanjar, 2006, Rahasia Sukses Membangkitkan ESQ POWER Sebuah Inner Journy Melalui Al-Ihsan, (Jakarta: ARGA).

Chambali, Soleh. 1951, Intan Berlian Laki Perempuan, (Surabaya: Penerbit Salim Nabhan dan Ahmad).

Eksan, Moch. 2000, Kiai Kelana Biografi Kiai Muchith Muzadi, (Yogyakarta: LKiS).

M. Sulton \& Moh. Khusnuridlo, 2006, Manajemen Pondok Pesantren Dalam Perspektif Global, (Yogyakarta: Laks Bang PRESSindo).
Ma'arif, A.Syafi'I, dkk., 1991, Pendidikan Islam di Indonesia antara Cita dan Fakta, (Yogyakarta: Tiara Wacana).

Quthb Muhammad, 1993, Sistem Pendidikan Islam terj. Salman Harun, (Bandung: Al Maarif).

Soebahar, Abd Halim, 2003, Matrik Pendidikan Islam, (Jakarta: Kalam Mulia),

Zamroni, 2001, Paradigma Pendidikan Masa Depan, (Yogyakarta: Bigraf Publishing)

Badan Pengembangan dan Pembinaan Bahasa. Pedoman Umum Ejaan Bahasa Indonesia (PUEBI). Jakarta: Kementerian Pendidikan dan Kebudayaan, 2016.

Majid, A, \& Dian, A. (2013). Pendidikan Karakter Perspektif Islam. Bandung:Remaja Rosdakarya

Daradjat, Z. (1995). Pendidikan Islam dalam Keluarga dan Sekolah .Jakarta:Ruhana

Elmubarok, Z. (2007). Membumikan Pendidikan Nilai Mengumpulkan yang Terserak, Menyambung yang Terputus, dan Menyatukan yang Tercerai.Bandung:Alfabeta 